MacGregor Susanne (Orcid ID: 0000-0002-0317-3850)

\title{
ADDICTION CLASSICS
}

\section{The Pub and the People. A Worktown Study by Mass Observation}

Susanne MacGregor

Centre for History in Public Health, London School of Hygiene and Tropical Medicine, University of London, UK

Email Susanne.MacGregor@LSHTM.ac.uk

Running head - The Pub and The People

Word count 3191 words plus references

Declaration of interests: none

\section{ADDICTION CLASSICS}

Mass Observation was an independent social research organisation which, between 1937 and 1949, documented the attitudes, opinions and everyday lives of the British people, using a combination of anthropological fieldwork, opinion surveys and written testimony. The Pub and the People is a classic text for its distinctly sociological approach, seeing patterns of drinking and socialising in context rather than focusing primarily on pathological consequences. The main conclusions were that the pub is a living social organism and that the traditional approach of British sociology, which, MO argued, focused on 'the drink problem' and the links between alcohol, crime and delinquency, failed to take account of the full social context. Mass Observation's focus on the pub as a place anticipates themes taken up in work on alcohol in cultural geography. Later alcohol researchers and epidemiologists have continued this orientation, recognising the importance of physical and social environments in relation to alcohol consumption. Other studies have built on the MO initiative by looking at how drug and alcohol consumption links to identity, friendship and sociality or at the connections between intoxication and pleasure. The value of this classic text is that it reminds us that paying attention

This article has been accepted for publication and undergone full peer review but has not been through the copyediting, typesetting, pagination and proofreading process which may lead to differences between this version and the Version of Record. Please cite this article as doi: 10.1111/add. 15220 
to the social context is not just a useful supplement but absolutely central to understanding the use of alcohol or drugs.

\section{Mass Observation}

Mass Observation (MO) was founded in UK by Tom Harrisson and Charles Madge in the late 1930s. Madge was developing a new science of 'mass observation - an anthropology of our own people' (1) while Harrisson had already set up an anthropological project of his own - Worktown - to study everyday working class life in Bolton, Lancashire, selected as an archetypal northern industrial town.

The Worktown/ Bolton enterprise was at times disorderly and unsystematic but often a lot of fun. Volunteer students, graduates and locals (some of whom later became prominent politicians or writers) participated in the fieldwork. MO pioneered an eclectic mix of methods - 'impressionistic (great swathes of colour) but also pointillist (neat nuggets of fact)' (2). MO claimed to be an alternative to the then orthodox British social survey, which was obsessed, they thought, with 'the typical, the representative and the "statistical sample"' (3). Instead their researchers would 'plunge deeply under the surface of British life and become directly acquainted with the mass of people who left school before they were $15^{\prime}(4)$.

This MO method has been criticised for its 'relentless empiricism' ... at times a 'seemingly unsystematic collection of often trivial observations' (5). Harrisson, previously an ornithologist and anthropologist, said that the key to objective reporting was watching and listening. They tried to observe without being observed. The overall approach was documentary: 'people are followed, behaviour painstakingly observed, conversations recorded, actions counted' (6). Rarely were direct questions asked: 'What people say is only one part sometimes a not very important part - of the whole pattern of human thought and behaviour' (7). Harrisson claimed that the teams conducted their research practically unnoticed, although one wonders whether this was always so. The observers were almost all men: the gender bias is the main distortion, even more than the class bias, for their public school/ Oxbridge character was somewhat balanced by additionally recruiting intelligent, self-educated local men. 


\section{The Pub and the People}

Of the 23 books and pamphlets MO produced between 1937 and 1950, The Pub and the People (1943) is the only one based entirely on the Worktown study, originally known as the South Lancashire Cultural Survey. It was meant to be one of a series of four volumes on life in Bolton (Worktown). The other topics were to be 'religious life', 'the week's holiday in Blackpool' and 'politics and the non-voter'. In the event (largely World War Two) it was the only one to appear. John Sommerfield, 'soldier, adventurer, social explorer and writer' (8) was responsible for the first draft of the book, which was ready by autumn 1938, but neither Harrisson nor the publisher Gollancz was satisfied with it. The text went through a series of revisions and rewriting and in places the seams do show. As key people were drafted into war work, the effort languished. Eventually, Harrisson and Sommerfield produced a shorter version and in 1942 Gollancz agreed to publish. The book was reviewed favourably by George Orwell in The Listener, in January 1943.

\section{A distinctive sociological perspective on alcohol and drink}

For $\mathrm{MO}$, the pub offered a window into the lives of ordinary British working people, focusing particularly on their leisure time. Human behaviour was observed in everyday surroundings - in this case the familiar territory of the pub. The Pub and the People is a classic text for its distinctly sociological approach, looking at the pub as a social institution, and seeing patterns of drinking and socialising in context rather than focusing primarily on pathological consequences.

The key theme is that people rarely go to pubs just to get drunk: rather they go to share in conviviality and conversation. Most studies of alcohol at the time were positioned within surveys of the poor and poverty, often concentrating on 'the drink problem'. By contrast, $\mathrm{MO}$ was interested in social influences on drinking, both customary and more recent - for example, noting the role of advertising, which at the time promoted beer as a healthy drink. MO were keen to describe going to the pub as a positive leisure activity - a counterweight to what they termed 'propaganda against pubs ... which particularly comes from about a third of the leaders in the town's public life' (9). Ambivalent attitudes to drinking were internalised by pub-goers, 
surrounded as they were by conflicting advice from churches and advertising. 'Beer more than anything else has to overcome guilt feelings' (10).

There were numerous fieldworkers but Bruce Watkin, an Oxford student, helped especially. They spent a lot of time in the pub, observing and listening in on conversations. Detailed scrutiny revealed differences between men's and women's behaviour - for example, that in the main men paid for the women's drinks and it was more respectable for women to drink bottled rather than draught beer. Some additional subjective information was gathered, as when local people were asked to contribute pieces on 'why I drink beer', using the local newspaper to access respondents.

These observations were supplemented by other data, especially historical records and published statistics. MO saw the pub as providing an alternative to the principal non-work institutions in the town - religion and politics. For MO, leisure activities in the pub were a release after the daily and weekly round of hard, tightly regulated toil in factory or mill.

\section{Key insights}

At this time, the pub was a feature of all life in Worktown. Just before the War, a pub could be found on the corner of any terraced street. A key division was between these 'locals' and the town centre pubs, with a count showing that 90 per cent of pub regulars did not walk more than 300 yards to get to their usual pub (11). The town centre pubs had a different pattern of drinking, higher prices, different clientele and more women, and linked into the shopping and bright lights districts with their cinemas and dance halls.

Critically the pub was not just a place to drink but a place to talk, smoke, spit, play games, bet, sing and listen to the piano. It was the location for weddings, funerals and secret societies as well as some petty crime and prostitution. Most importantly, it was also where conversations took place with topics ranging widely - over 'Power of earth as source of life - Indestructability of matter - Transfer of a player from the town team - Food and its adulteration as a cause of national decadence - Power of Dictators ... Privileges of the land owning classes' etc etc (12).

MO described social status differences with dress and clothing being key markers - caps, trilbies and bowler hats - or choice of place to drink - 
taproom, vault, parlour or lounge - whether sitting or standing, or what type of drink and when - beer predominated among men with women drinking stout, Guinness, brown ale or port, and weekend drinks differing from those during the week. Most alcohol was drunk in the last hour and speed of drinking increased on a Friday. Monday to Thursday were the hard up days (13) with most money spent at weekends and most drinking happening on Saturdays (Saturday night was a big pleasure night in Worktown, the night not only for alcohol but also sex, and fish and chips).

At this time, in these pubs, drink equalled beer: over half of Worktown's 304 pubs did not sell spirits (14). MO noted the role of the brewers in the local political economy (two landlords and a brewer sat on the town council) and analysed the complex processes of production as well as consumption of beer. They described the many varieties of beer - strong, bitter, light and mild, and pale ale. Prices differed depending on the room where consumed, with the heavy drinker being the man in the vault or taproom (15). They also described the different roles performed in these settings, looking at the special functions and backgrounds of the publican, the barman and barmaid and the almost pastoral relation that existed between the landlord and the regulars.

The most famous chapter in the book is probably chapter 6 which looks at Drinking. It describes the slow savouring involved in the act of drinking beer. Attention is given to the conventions and habits surrounding the act of drinking, the shared patterns and rates of drinking when in groups and the ritual of 'standing rounds' (16).

MO's method here is similar to some of the early time and motion studies conducted in industrial settings. The detail is extraordinary - and one does wonder if the researchers were entirely serious in recording some of this information. To give just one example: MO measured the time it took to drink a gill of beer: ' 63.8 per cent of all times were between 6 and 10 minutes, the day's average being 9.7 minutes' (17). However, all this detail did allow them to conclude that 'there is a definite tendency for group drinking to be faster than solitary drinking' (18). The principle here was to stress the social nature of drinking, that time taken to drink differed by location and day of the week thus showing that there are patterns to drinking, separate from individual predispositions and motivations.

MO observed the ritual of group drinking in detail. They showed the stigma attached to those who did not carry out their duty to 'stand a round' when it 
was their turn. MO went on to conclude that there were important social values at the core of what they characterised as an essentially egalitarian and democratic custom.

There are other chapters on Drunks; Singers and Pianists: Bookies and Prostitutes; Sports, Games and Gambling; Non Drinking; and The Last Hour which are all illuminating. The main conclusion was that the pub is a living social organism and that the traditional approach of British sociology, which seemed to MO to focus on 'the drink problem' and the links between alcohol, crime and delinquency, was extremely partial and failed to take account of huge parts of the social context and the importance of the social relations and cultural values that surround the act of drinking - 'there is a lot more than drinking involved in drinking' (19).

\section{Critique and evaluation}

Mass Observation made great play of their pioneering methods and perspective, setting themselves apart from the administrative sociology which predominated in Britain at the time. Tom Harrisson and John Sommerfield, the principal authors, felt more at home with the work of Chicago sociologists like Robert Park and E W Burgess whose influence was eventually seen in British sociology from the 1960s onwards.

There are many gems of observation such as 'one aspect of drinking is that it is an attempt to escape from time, to change the rhythms of living, the speed of thinking' (20) set within other details which have the quality at times of scientism/ raw empiricism. This aspect of the approach is illustrated in one table which shows: the ratio of caps to non-caps; and seats to spittoons; in the best room; of four pubs; taken at random; on January $24-28$. And in another table showing how spittoons were used - for matches, fag ends or spit, correlated with the time of the evening and the number of men present (21). This little project concluded that 'fag ends and 17 spits is a pretty average Saturday.'

But were $\mathrm{MO}$ as detached and impartial as they claimed to be? Some have characterised the Worktown project as an encounter between upper/ middle class intellectuals and the Bolton working class. At times, one wonders if their subjects were not pulling their legs. They were surely not as hidden and 
discrete as they thought they were - with one man they tried to engage in conversation responding, 'what the bloody hell it's got to do with you?' (22).

Innovative methods such as involving local fieldworkers or photo-ethnography are to be found within the broad canvas of the portrait of pubs in Worktown. In their search for understanding and in their methods, $\mathrm{MO}$ anticipated many later developments in cultural studies and ethnomethodology. Their focus on the pub as a place led on to themes taken up in work on alcohol in cultural geography (23). Geography focuses on space and place while cultural studies look at meanings and practices in political and social contexts. Such research has described and analysed drinking cultures and shown how they are changing: for example, with the impact of supermarket sales; differences between drinking at home and drinking in public or commercial spaces; and at differences within and between subcultures, genders, and ethnic groups. Topics which parallel some of MO's interests include alcohol consumption on holiday (24) and the distinctiveness of city centre drinking (25). More recent work has tended to focus on young people or on problems, not an aspect of the $\mathrm{MO}$ approach. Alcohol researchers since have also recognised the importance of physical and social environments as they relate to alcohol consumption, often with attempts to identify factors amenable to intervention and again a tendency to focus on young people. Recent 'event-level' alcohol research echoes $\mathrm{MO}$ with its interest in recording the characteristics of drinking contexts. There are also parallels with trends in alcohol epidemiology, such as spatial mapping of alcohol outlet density and harms and using ecological momentary assessment to track the temporalities of drinking (2630).

MO's meticulous and precise observations were also set within excursions into social theory with interpretations concerning the tension between the individual and community - voicing disquiet about social and cultural trends all of which became familiar themes in late $20^{\text {th }}$ and $21^{\text {st }}$ century sociology with discussions of the influence of commercialisation, privatisation, and marketisation. For example, MO regretted contemporary social changes which challenged the position of the pub in social life, singling out for comment the increasing influence of the 'pools' (betting on football scores), television, and the cinema.

The style of the wide-ranging commentary found within The Pub and the People differs from the professionalised, more anodyne and sometimes jargon- 
ridden sociology of post-war years. MO were also interested in linking their social research to the wider community by, for example, arranging exhibitions. Theirs was not a purely academic enterprise - they were not funded by research councils or based in university departments: we 'did not receive one shilling of support from academic quarters' (31). MO positioned themselves as outsiders and young rebels against the British social survey tradition in sociology. In this regard, they were however not quite so distinctive as they claimed. The founders of British social science, Charles Booth and Seebohm Rowntree, were themselves critics of prevailing moral orthodoxies and their social investigations aimed at a new science - in their case statistics. Their studies too contained direct observations and impressions and recorded social worlds and customs that were fast disappearing. Booth in identifying the causes of poverty ranked alcohol low on his list, below such factors as unemployment and low wages (32).

Later studies (perhaps unknowingly) built on the MO initiative when they looked at how drug and alcohol consumption relates to identity, friendship and sociality, on the assumption that 'the conditions under which drugs and alcohol are consumed are inescapably socially defined' (33). A body of research by Geoffrey Hunt and colleagues stands out with their emphasis on the links between intoxication and pleasure and their attention to the social context of drinking and drug-taking (34). For these researchers, paying attention to the social context is not just a useful supplement but absolutely central to understanding anything about the use of alcohol or drugs.

The Pub and The People was a study of the pub as a social institution, focusing on the influence of space and time in the social construction of drinking patterns. Later work has given more attention to issues of race and gender which are missing in The Pub and the People, although there is some discussion of the Irish. However, the crucial insight of this MO study - that drinking took place alongside other activities like talking, gambling, or playing dominos, and cannot be understood without noting this - remains important for alcohol studies. Drink in western societies continues to play a large part in cementing friendships and developing a community spirit whether this be at local level or in work groups or other social organisations. 


\section{Future of the pub}

Even in 1940, MO observed that the pub was then playing a smaller part in the life of the town than it ever did (35). World War Two transformed pub life, with Orwell commenting that in that short period of time, beer has doubled in price and been heavily diluted' and that 'in the past seventy years the annual consumption of beer per head has decreased by nearly two-thirds'(36). The changing nature of the pub has been examined in histories of alcohol (37) but there remains a need for contemporary sociology to return to the study of the pub itself and its importance in social and cultural life (38).

The Mass-Observers' conclusion was that 'the pub as a cultural institution is at present declining' (39) not merely because of persecution by Nonconformist Town Councils, but because 'the whole trend of the age is away from creative communal amusements and towards solitary mechanical ones' (40). Their contribution to cultural studies focused on a shift of people's leisure from active and communal to passive and individual. Both $\mathrm{MO}$ and Orwell were exhibiting that perennial tendency to point to the 'decline of civilisation as we know it' which has its parallels in much of today's discussions of post-modern culture's atomisation and individualisation. MO commented that 'all the older institutions are declining' (41) not only the pub but the church, politics and pigeon racing. They decried the attractions of the new pleasures found in the football pools, the cinema, radio, television and small cars, all consumed individually or in privatised families rather than communally. These new institutions were promoted by marketing - anticipating recent complaints about 'commercialisation' in 'neo-liberal societies'. The regrets voiced in Harrisson's digressions (scattered among the careful fieldwork observations) have their parallels in much later critical sociology. In spite of the aim at objectivity, values and assumptions are clearly visible throughout this book.

In post-war years, the pub with its beer and spirits has had to compete with television, home drinking, wine bars, clubs and recreational drugs. Reluctantly announcing the Coronavirus Lockdown earlier this year, UK Prime Minister Boris Johnson said he regretted 'taking away the ancient and inalienable right of every freeborn Englishman to go to the pub'. Even in wartime, pubs stayed open. Yet before the pandemic, it had been noticed that across the country pubs were closing down, with the land redeveloped into flats, changing the face of neighbourhoods. And today there are serious worries about how they will be able to function in the 'new normal' created by COVID-19. However, the 
pub throughout its long history has shown a remarkable ability to survive by adapting to changing circumstances (42) and we must hope that, as it is forced to react to the demands of social distancing, this ingenuity will once more be displayed.

\section{References}

\section{The Pub and the People. A Worktown Study by Mass Observation}

(Mass Observation Archive 1943); London, V. Gollancz Ltd., 1943; Seven Dials Press 1970 ISBN 10.0851290507 includes photographs by Humphrey Spender ; The Cresset Library, Century Hutchinson Ltd, London 1987 (with Introduction by Godfrey Smith and appendix by Dorothy Sheridan) ISBN 0 - 09-170421-9; Faber and Faber Ltd, London 2009 ISBN 978-0-571-25095-0

1 Hinton J. The Mass Observers: A History, 1937-1949 Oxford University Press; 2013: 1

2 Smith G. 'introduction' to The Pub and The People, The Cresset Library, Century Hutchinson Ltd, 1987: x

3 Harrisson T. 'Preface' to The Pub and The People, 1943: xvi.

4 ibid

5 Hinton J. 2013: 31

6 Sheridan D. 'Appendix' to The Pub and The People, 1987: 352.

7 Harrisson T 'Preface', August 1942 to The Pub and The People, 1987: xvii

8 Hinton J. 2013: 23

9 The Pub and The People, 1987: 45

10 The Pub and The People, 1987: 45

11. The Pub and The People, 1987: 33

12 The Pub and The People, 1987: 187.

13 The Pub and The People, 1987: 116 
14 The Pub and The People, 1987: 48 and 67

15 The Pub and The People, 1987: 33

16 The Pub and The People, 1987: 169

17 The Pub and The People, 1987: 173

18 The Pub and The People, 1987: 173

19 The Pub and The People, 1987: 167.

20 The Pub and The People, 1987: 199

21 The Pub and The People, 1987: 205

22 The Pub and The People, 1987: 131.

23 Jayne M, Valentine G. and Holloway S. L. Alcohol Drinking Drunkenness: (Dis) orderly spaces, Ashgate 2011

24 Jayne M, Gibson C, Valentine G 'Drunken mobilisation: backpackers, alcohol, “doing place"' Tourism Studies 2012: 2 (3): 211-31

25 Hobbs D, Hadfield P, Lister S and Winslow S Bouncers: Violence and Governance in the Night Time Economy Oxford: Oxford University Press, 2003; Plant M and Plant M Binge Britain: Alcohol and the National Response Oxford: Oxford University Press, 2006.

26 Strauss R and Bacon S Drinking in College Yale University Press: NY, 1953

27. Clapp J D \& Shillington A M 'Environmental predictors of heavy episodic drinking' The American Journal of Drug and Alcohol Abuse, 2001; 27:2, 301313, DOI: 10.1081/ADA-100103711

28. Clapp, J.D., Lange, J., Min, J.W. et al. 'Two Studies Examining Environmental Predictors of Heavy Drinking by College Students'. Prev Sci 4, 99-108 (2003). https://doi.org/10.1023/A:1022974215675

29. Britt H T, Carlin B P, Toomey T L and Wagenaar A C 'Neighbourhood level spatial analysis of the relationship between alcohol outlet density and criminal violence' Environmental and Ecological Statistics 2005: 12; 411-426

30. Kuntsche $E$ and Labhart $F$ 'Investigating the drinking pattern of young people over the course of the evening at weekends' 2012 Drug and Alcohol Dependence 2012 doi: 10.1016/j.drugalcdep 2012.02.001 
31. The Pub and The People, 1987: 4

32. Booth C Life and Labour of the People in London, Macmillan and Company, Limited, 1902; Rowntree B S Poverty: A study of town life, Macmillan 1901; Morgan M S (editor) Charles Booth's London Poverty Maps, Thames and Hudson 2019; Light A 'The general tone is purple' Review of Morgan M S 2019 in London Review of Books 2 July 2020: 17-20

33. Thurnell-Read T. 'Identity, friendship and sociality' in Sage Handbook of Drug and Alcohol Studies (Edited by T. Kolind, B. Thom and G. Hunt) 2017; 337. 34. Hunt G, Moloney M. and Kristen E. Youth, drugs and night life Routledge 2010

35. The Pub and The People, 1987: 74.36. Orwell G. Review of The Pub and The People V. Gollancz Ltd., The Listener, 21 January 1943.

37. Nicholls J. The Politics of Alcohol: a history of the drink question in England Manchester University Press 2009

38. Markham C. 'Why now is the time for pubs to become a staple of sociological research' 23 April 2020 Everyday Society https://es.britsoc.co.uk/whynow-is-the-time-for-pubs-to-become-a-staple-of-sociological-research/

39. The Pub and The People, 1987: 218

40. Orwell G Review of The Pub and The People V. Gollancz Ltd., The Listener, 21 January 1943.

41. The Pub and The People, 1987: 76

42. Nicholls J. The Politics of Alcohol: a history of the drink question in England, Manchester University Press 2009 